\title{
PHYSICO-CHEMICAL STUDIES AND MICRONUTRIENT STATUS IN BOREWELL IRRIGATION AGRICULTURE LAND AREA OF MAYILADUTHURAI TALUK IN MAYILADUTHURAI DISTRICT-TAMIL NADU, INDIA
}

\author{
P. Juliat Mary ${ }^{a^{*},}$ A. Arokiyaraj ${ }^{\text {b }}$, S. Leo Arokiaraj ${ }^{c}$ and R. Maria Arul Antony ${ }^{d}$. \\ ${ }^{a *}, b \& c$ Department of Chemistry, *A.V.C. College (Autonomous), Mannampandal- 609 305, \\ Mayiladuthurai District. \\ dAbu Dhabi Nation oil Company, Mayiladuthurai. \\ *Institute Affiliated to Bharathidasan University, Tiruchirappalli-620024. \\ julymphil@gmail.com ${ }^{*}$, arochemmyl@gmail.com ${ }^{b}$,matha.leo@gmail.com ${ }^{C}$ and \\ mariaarula@adnoc.ae .
}

\begin{abstract}
Micronutrients are essential elements needed in small quantities for the growth of plants. The micronutrients are $\mathrm{Fe}, \mathrm{Mn}, \mathrm{Zn}, \mathrm{Cu}, \mathrm{B}, \mathrm{Mo}, \mathrm{Co}$ and $\mathrm{Cl}_{2}$. These micronutrients will balance antagonistic and synergetic effects if they are present in excess or in deficiency level. In this study assess the micronutrient status of $\mathrm{Fe}, \mathrm{Mn}, \mathrm{Zn}$ and $\mathrm{Cu}$ in Mayiladuthurai Taluk of Mayiladuthurai District, Tamil Nadu State by using Atomic Absorption Spectrophotometer. The results revealed that the order of mean status of available micronutrients was found to be Fe $\left(4.95 \mathrm{mg}^{\mathrm{kg}} \mathrm{kg}^{-1}\right)>\mathrm{Mn}(2.94$ $\left.m g . \mathrm{kg}^{-1}\right)>\mathrm{Cu}\left(1.16 \mathrm{mg} . \mathrm{kg}^{-1}\right)>\mathrm{Zn}\left(0.86 \mathrm{mg} . \mathrm{kg}^{-1}\right)$. On an average basis 12.19, 26.82, 90.24 and 90.24 percent soils were found to be deficient in $\mathrm{Fe}, \mathrm{Mn}, \mathrm{Cu}$ and $\mathrm{Zn}$ respectively.
\end{abstract}

Keywords: micronutrients, bore well irrigation, Mayiladuthurai Taluk, soil, Tamil Nadu.

\section{Introduction}

In this present study assess the agriculturally important micronutrients such as $\mathrm{Fe}, \mathrm{Mn}, \mathrm{Zn}$, and $\mathrm{Cu}$. All are essential for plant growth and are required in such small quantities that they are called micronutrients or tracer elements. The enrichment or the deficiency of the micronutrients presence such as $\mathrm{Fe}, \mathrm{Mn}, \mathrm{Zn}$ and $\mathrm{Cu}$ may produce synergetic and antagonistic effects in plants (Jagodin, 1975). The micronutrients are required in very small quantities and they will be harmful when the available forms are present in the soil in large quantities (Mhatre and Chaphekar, 1982). The concentration range of the micronutrients will help in the grow of plants satisfactorily which is considerably small. The indiscriminate use of micronutrients is not really advisable because the small amounts will interaction with other nutrients. The lack of Information about the status of micronutrients in various villages at Tamil Nadu. Although, widespread micronutrient deficiency has been observed in the soils of Trichy District of Tamil Nadu (Martin Devaprasath, 2008), and also micronutrient deficiency has been observed in the soils of Nagapattinam District of Tamilnadu (A.Arokiyaraj et al, 2011), the information with respect to availability of micronutrient status of the study area was lacking include copper deficiency (Ruiter HJ 1969). A soil analysis was proposed systematically to delineate areas of individual micronutrient deficiencies in the study area at Mayiladuthurai Taluk of Mayiladudurai District in Tamilnadu. In this study, an attempt has been made to assess the micronutrient status of $\mathrm{Fe}, \mathrm{Mn}, \mathrm{Zn}$ and $\mathrm{Cu}$ in the soils of all the 41 revenue villages in Mayiladudurai Taluk using Atomic Absorption Spectrophotometer. The location map of the Mayiladuthurai Taluk is given in Figure No-1. 


\section{Study Area}

Mayiladuthurai Taluk of Mayiladuthurai District is being selected as a study area which is situated near coastal region in the southern Tamilnadu State located in the coastal region of Bay of Bengal 11.0290373 Latitude and 79.8506815 Longitude. The Agricultural Land is spread over 27,726 hectares at Mayiladudurai Taluk. Figure No-1 shows the study area. The area is intensively cultivated in an array of crops such as rice, cereal, sugar cane, banana, and cotton. The length of the growth period is 90-150 days. It is characterized by a long dry season from October through May/June and a short but intense wet season from May/June through September with mean annual rainfall slightly below $750 \mathrm{~mm}$, Shows a marked seasonal The rainfall pattern variation with a single peak reaching maximum in August.

\section{Mayiladuthurai Taluk in Mayiladuthurai District}

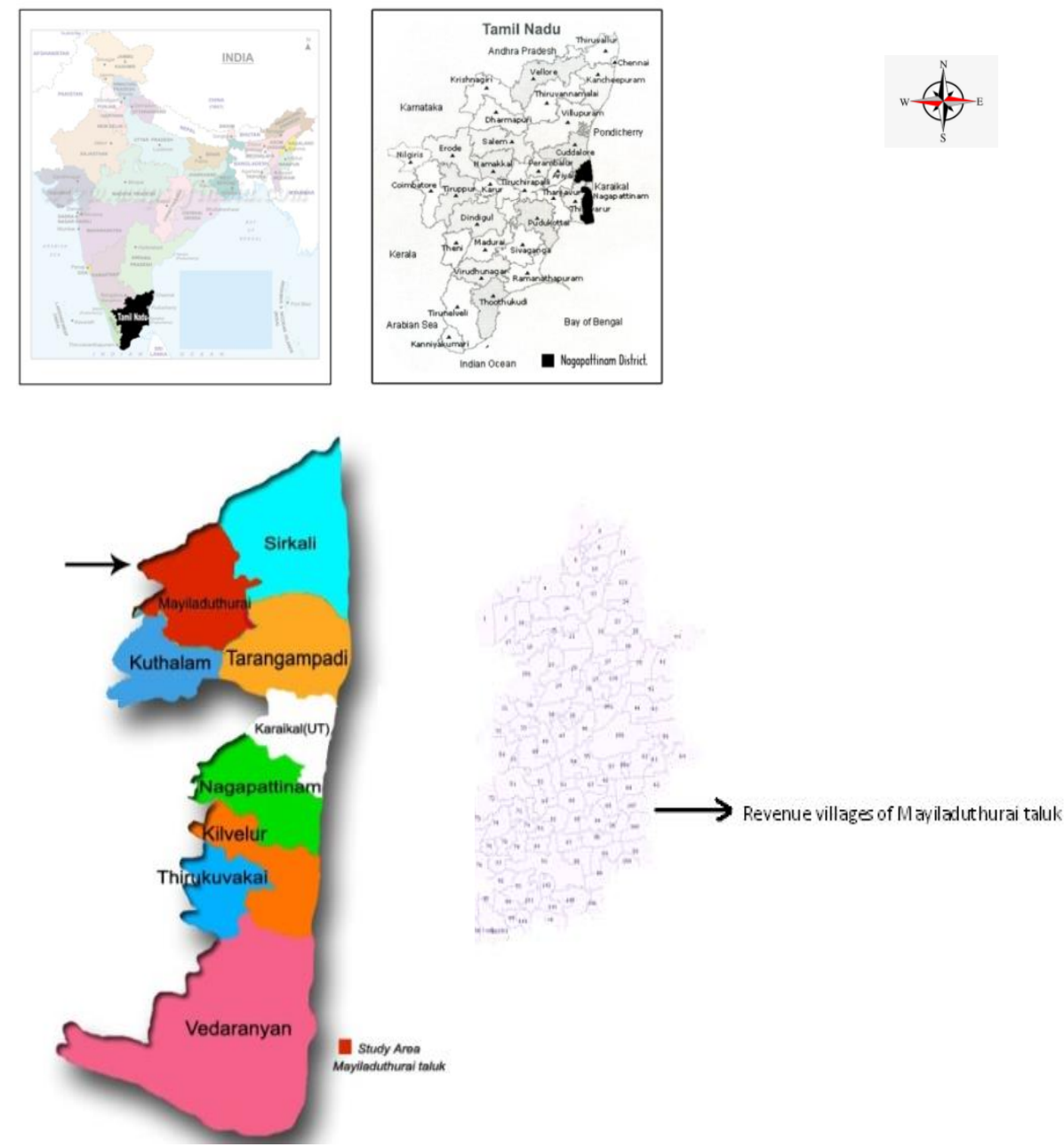

Figure No-1 Location Map 


\section{Materials and Methods}

Surface soil samples depth $(0-20 \mathrm{~cm})$ numbering 205 from 41 revenue villages in Mayiladudurai Taluk of Mayiladudurai District were collected. Five samples were collected from each revenue village.

The soil samples were collected and passed through $2 \mathrm{~mm}$ sieve. The analysis done for DTPA (Diethylene Triamine Penta Acetic acid) to extract micronutrients ( $\mathrm{Fe}, \mathrm{Mn}, \mathrm{Zn}$ and $\mathrm{Cu}$ ) as per the method suggested by (Lindsay and Norvell, 1978) and the concentrations of $\mathrm{Fe}, \mathrm{Mn}, \mathrm{Zn}$ and $\mathrm{Cu}$ were determined using to determine Atomic Absorption by Spectrophotometer. Averaging of soil test values simply for each micronutrient which is done to get the average status in the villages.

The critical levels fixed by earlier analysts for DTPA extractable micronutrients in Tamil Nadu soils, the percentage deficiencies of individual nutrients were calculated in each village. Fixing of critical ranges for DTPA extractable micronutrients as recommended by (Tandon, 1999) as follows:

$$
\begin{aligned}
& \mathrm{Fe}-3.7 \mathrm{mg} \mathrm{Kg}-1 \\
& \mathrm{Mn}-2.0 \mathrm{mg} \mathrm{Kg}-1 \\
& \mathrm{Zn}-1.2 \mathrm{mg} \mathrm{Kg}-1 \\
& \mathrm{Cu}-1.2 \mathrm{mg} \mathrm{Kg}-1
\end{aligned}
$$

\section{Results and Discussion}

The village wise DTPA-extractable micronutrients ( $\mathrm{Fe}, \mathrm{Mn}, \mathrm{Zn}$ and $\mathrm{Cu}$ ) contents were systematically determined for Mayiladudurai Taluk of Mayiladudurai District and the mean values of the micronutrients status of Mayiladudurai Taluk villages are given in Table- 1 . Analysis of 205 surface soil samples collected from Mayiladudurai Taluk (41 revenue villages) revealed that DTP A extractable micronutrient content in Mayiladuthurai Taluk soils with a mean status of $0.86,1.16,4.95$ and $2.94 \mathrm{mg} \mathrm{kg}-1$ for $\mathrm{Zn}, \mathrm{Cu}, \mathrm{Fe}$ and $\mathrm{Mn}$ respectively. Figure No-2.

Out of 205 samples analyzed in the Bore well irrigation Agriculture land area of Mayiladudurai Taluk of Mayiladudurai District, 12.19, 26.82, 90.24 and 90.24 percent soils were found to be deficient in $\mathrm{Fe}, \mathrm{Mn}, \mathrm{Zn}$ and $\mathrm{Cu}$ respectively (Figure No-4) and the extent of micronutrients deficiency in Mayiladudurai Taluk of Mayiladudurai District is presented in Table-3.

The content of $\mathrm{Zn}, \mathrm{Fe}, \mathrm{Cu}$ and $\mathrm{Mn}$ varied from 0.62-1.52, 3.53-10.37, 0.72-8.14 and 1.73$8.14 \mathrm{mg} \mathrm{kg}-1$, with mean values of $0.86,4.95,1.16$ and $2.94 \mathrm{mg} \mathrm{kg}-1$ respectively. On the basis of the critical limits suggested by (Tandon, 1999), (<1.2 mg kg-1 for deficient and $>1.2$ mg kg-1 for sufficient) all the $90.24 \%$ villages were deficient in the available $\mathrm{Zn}$. Considering the critical limits (3.7 mg kg-1) proposed by (Tandon, 1999), $12.19 \%$ villages were found to be deficient in DTPA extractable Fe. Similarly $26.82 \%$ of villages were deficient in the available $\mathrm{Mn}$ and $90.24 \%$ villages were deficient in the available $\mathrm{Cu}$ when considering the critical limits suggested by (Tandon, 1999), [2.0 mg kg-1 for Mn and $1.2 \mathrm{mg}$ kg-1for $\mathrm{Cu}$.

The results showed that $\mathrm{Zn}$ deficiencies in $90.24 \%$ villages were recorded in the study area. The deficiency of Zinc which leading to disordering the nutrients widespread to various crops. The mean available $\mathrm{Zn}$ content was also found to be below the critical level $(0.86 \mathrm{mg}$ 
$\mathrm{kg}$-1). In general, the deficiency of $\mathrm{Zn}$ was pronounced in most of the villages of the Taluk. Rice is the major grown crop in Mayiladudurai Taluk of Mayiladudurai District and all the crops are mostly grown under irrigated conditions. The chemistry of submerged soil, Bicarbonate rich ground water, mostly or partly composed of calcium carbonate and poor organic matter status may be reasons for $\mathrm{Zn}$ deficiency. In crop growing areas, indiscriminate use of phosphate fertilizers and copper fungicides may also be attributed for $\mathrm{Zn}$ deficiency. In case of field crops, soil application of $\mathrm{ZnSO} 4,15-25 \mathrm{~kg} / \mathrm{ha}$ can be done before sowing or transplanting. Foliar sprays of $0.5 \% \mathrm{ZnSO} 4,2-3$ times at 10-15 days interval can be effective in correcting $\mathrm{Zn}$ deficiency in standing crops. Various agricultural growths like Rice, Sugarcane, maize, banana, groundnut, citrus and others may respond well to $\mathrm{Zn}$ fertilization especially in case of or partly composed of calcium carbonate, ill drained $\mathrm{P}$ rich soils. In such cases, foliar nutrition of $\mathrm{Zn}(0.2-0.5 \%)$ of $\mathrm{ZnSO} 4$ sprayed at 2-3 times may be a viable option. Application of $\mathrm{Zn}$ further along with organic manures may enhance the availability and efficiency of native $\mathrm{Zn}$ through chelation.

Fe deficiency was found to be $12.19 \%$ in the study area. Fe deficiency may be due to poor water quality (CaCl2/CaHCO3 types), calcareousness and alkaline $\mathrm{pH}$. Among all the villages, Thiruvalaputhur village registered a maximum mean Fe value of $10.37 \mathrm{mg} \mathrm{kg}-1$ owing to the garden land conditions prevalent in this area.

Among the 41 villages of the Taluk $90.24 \%$ deficiency of $\mathrm{Cu}$ was observed. The available $\mathrm{Cu}$ Content variation in all Mayiladudurai Taluk may be attributed to the differences in all the Texture, topography and organic matter content present in the soils. Commonly the low critical value (1.08 $\mathrm{mg} \mathrm{kg} \mathrm{-1)} \mathrm{of} \mathrm{Cu}$ may be due to its incorporation in living systems when the atmosphere shifts from reducing to oxidizing state (Broda, 1975). Whenever $\mathrm{Cu}$ deficiency is noticed in standing crops, 2 to 3 foliar sprays of $0.025 \% \mathrm{CuSO} 4$ can be done before flowering. Let us suppose Agricultural growths crops like rice, banana and sunflower; foliar application of $\mathrm{CuSO} 4$ either singly or in combination with other micronutrients may enhance yield as well as the quality of the product.

Manganese is crucial to all plants and is responsible for the production of molecular oxygen in plants during photosynthesis (Saucer 1980). The deficiency of Mn leads to infertility. Mn deficiency from the study area was found to be 26.82 percent. Whereas compared to the other micronutrients, Manganese is significantly, adequately present in all the villages and this result corroborate with the findings of (Sharma et al., 2006). In certain circumstances, where its deficiency may arise due to excessive levels of $\mathrm{Fe}$ and calcareousness. Corrective measures may be done through foliar application of $\mathrm{MnSO} 4$. Jetting of MnSO4 before first Spraying is preferable for most crops $(0.5-1 \% \mathrm{MnSO} 4$ spraying repeated 2 to 3 times at weekly intervals. In Mn deficient areas, crops like rice, sorghum, groundnut, sugarcane and finger millet may respond well to its applications. 
Table-1. Average Mean value of $\mathrm{pH}, \mathrm{EC}, \mathrm{OC}, \mathrm{Cu}, \mathrm{Fe}, \mathrm{Mn}$ and $\mathrm{Zn}$.

\begin{tabular}{|c|c|c|c|c|c|c|c|c|c|}
\hline \multirow[t]{2}{*}{$\begin{array}{l}\text { S. } \\
\text { No }\end{array}$} & \multirow[t]{2}{*}{ Name of the villages } & \multirow{2}{*}{$\begin{array}{l}\text { No. of } \\
\text { samples } \\
\text { collected }\end{array}$} & \multirow[t]{2}{*}{ pH } & \multirow[t]{2}{*}{$\underset{\left(\mathbf{d s m}^{-1}\right)}{\mathbf{E C}}$} & \multirow[t]{2}{*}{$\begin{array}{l}\mathrm{OC} \\
(\%)\end{array}$} & $\mathrm{Cu}$ & $\mathrm{Fe}$ & Mn & $\mathbf{Z n}$ \\
\hline & & & & & & \multicolumn{4}{|c|}{ Mgkg-1 $^{-1}$} \\
\hline 1 & Azhanthoppu & 5 & 7.64 & 0.32 & 0.37 & 1.03 & 4.02 & 1.76 & 0.73 \\
\hline 2 & Arkkadu & 5 & 7.58 & 0.35 & 0.41 & 0.82 & 4.12 & 1.76 & 0.73 \\
\hline 3 & Ayavallam & 5 & 7.6 & 0.32 & 0.43 & 0.76 & 4.09 & 3.36 & 0.72 \\
\hline 4 & Authur & 5 & 7.7 & 0.32 & 0.34 & 0.76 & 4.09 & 2.75 & 0.71 \\
\hline 5 & Arulmozhidevan & 5 & 7.6 & 0.29 & 0.4 & 0.75 & 4.06 & 2.77 & 0.69 \\
\hline 6 & Elanthoppu & 5 & 7.5 & 0.32 & 0.37 & 0.75 & 4.04 & 1.89 & 0.77 \\
\hline 7 & Kondel & 5 & 7.56 & 0.3 & 0.38 & 0.77 & 3.86 & 1.85 & 0.76 \\
\hline 8 & Kizhai & 5 & 7.56 & 0.24 & 0.42 & 0.74 & 4.16 & 1.83 & 0.71 \\
\hline 9 & Komal & 5 & 7.62 & 0.31 & 0.34 & 0.72 & 3.9 & 1.81 & 0.62 \\
\hline 10 & Kizhamaruthanthanallur & 5 & 7.6 & 0.24 & 0.42 & 0.73 & 3.89 & 1.83 & 0.63 \\
\hline 11 & Kottravanallur & 5 & 7.66 & 0.26 & 0.42 & 0.73 & 4.34 & 1.77 & 0.64 \\
\hline 12 & Kaduvangudi & 5 & 7.52 & 0.25 & 0.39 & 0.78 & 4.02 & 1.73 & 0.62 \\
\hline 13 & Kali & 5 & 7.62 & 0.25 & 0.4 & 0.9 & 4.05 & 1.76 & 0.65 \\
\hline 14 & Kuruchi & 5 & 7.68 & 0.29 & 0.34 & 0.89 & 4.3 & 2.29 & 0.75 \\
\hline 15 & Kottur & 5 & 7.62 & 0.26 & 0.46 & 0.89 & 4.74 & 2.11 & 0.87 \\
\hline 16 & Kadalangudi & 5 & 7.6 & 0.29 & 0.36 & 0.88 & 4.67 & 2.09 & 0.87 \\
\hline 17 & Kulathur & 5 & 7.66 & 0.29 & 0.42 & 0.89 & 4.66 & 2.07 & 0.86 \\
\hline 18 & Kanjanaharam & 5 & 7.62 & 0.3 & 0.37 & 0.88 & 4.74 & 2.35 & 0.85 \\
\hline 19 & Kezhaiyur & 5 & 7.6 & 0.29 & 0.37 & 0.89 & 4.74 & 2.16 & 0.84 \\
\hline 20 & Melamaruthanallur & 5 & 7.52 & 0.48 & 0.4 & 0.88 & 4.72 & 1.94 & 0.83 \\
\hline 21 & Melanallur & 5 & 7.5 & 0.36 & 0.38 & 0.88 & 4.23 & 3.17 & 0.81 \\
\hline 22 & Mudikondanallur & 5 & 7.6 & 0.33 & 0.43 & 0.88 & 3.77 & 3.77 & 0.83 \\
\hline 23 & Malliyakollai & 5 & 7.66 & 0.32 & 0.37 & 0.88 & 3.86 & 3.04 & 0.81 \\
\hline 24 & Melapathi & 5 & 7.64 & 0.48 & 0.43 & 0.88 & 3.84 & 2.97 & 0.79 \\
\hline 25 & Melaiyur & 5 & 7.54 & 0.41 & 0.35 & 0.87 & 3.79 & 3.38 & 0.79 \\
\hline 26 & Nidur & 5 & 7.7 & 0.39 & 0.4 & 0.86 & 3.69 & 3.28 & 0.78 \\
\hline 27 & ponvasanallur & 5 & 7.68 & 0.42 & 0.43 & 0.86 & 3.53 & 3.12 & 0.73 \\
\hline 28 & Panithalamedu & 5 & 7.64 & 0.31 & 0.28 & 0.86 & 3.62 & 3.11 & 0.7 \\
\hline 29 & Puthagaram & 5 & 7.62 & 0.38 & 0.32 & 0.86 & 3.68 & 3.08 & 1 \\
\hline 30 & Pattavarthi & 5 & 7.64 & 0.42 & 0.37 & 0.85 & 3.64 & 3 & 1.05 \\
\hline 31 & Pandur & 5 & 7.62 & 0.31 & 0.41 & 0.86 & 3.81 & 2.85 & 1.08 \\
\hline 32 & Radhanallur & 5 & 7.44 & 0.21 & 0.43 & 1.12 & 5.73 & 4.93 & 1.52 \\
\hline 33 & Sethur & 5 & 7.44 & 0.11 & 0.34 & 1.29 & 10.11 & 6.14 & 1.36 \\
\hline 34 & Thirvizhendhur & 5 & 7.48 & 0.11 & 0.45 & 0.77 & 5.14 & 4.09 & 0.94 \\
\hline 35 & Thiruvalaputhur & 5 & 7.36 & 0.1 & 0.39 & 0.75 & 10.37 & 3.2 & 0.74 \\
\hline 36 & Thalaignayaru & 5 & 7.4 & 0.11 & 0.4 & 0.84 & 9.16 & 3.84 & 0.79 \\
\hline 37 & Thalaignayaru-2 & 5 & 7.36 & 0.11 & 0.41 & 0.77 & 6.47 & 2.77 & 1.49 \\
\hline 38 & Utchamangalam & 5 & 7.44 & 0.1 & 0.39 & 0.76 & 8.9 & 2.72 & 1.49 \\
\hline 39 & Utthiragudi & 5 & 7.36 & 0.11 & 0.4 & 1.99 & 6.64 & 2.72 & 1.14 \\
\hline 40 & Villiyanallur & 5 & 7.44 & 0.11 & 0.46 & 8.14 & 6.39 & 8.14 & 0.88 \\
\hline 41 & Veppakullam & 5 & 7.36 & 0.11 & 0.37 & 5.5 & 7.68 & 5.5 & 0.7 \\
\hline \multicolumn{3}{|c|}{ Range } & 7.36-7.7 & $\begin{array}{l}0.1-0.48 \\
\end{array}$ & $0.28-0.46$ & 0.72-8.14 & 3.53-10.37 & 1.73-8.14 & $0.62-1.52$ \\
\hline \multicolumn{3}{|c|}{ Mean } & 7.56 & 0.27 & 0.39 & 1.16 & 4.95 & 2.94 & 0.86 \\
\hline
\end{tabular}


Table-2. Criteria for the assessment of Physico- Chemical parameters of soils

\begin{tabular}{|l|c|c|c|}
\hline $\begin{array}{l}\text { Physico- } \\
\text { Chemical } \\
\text { parameters }\end{array}$ & Low & Medium & High \\
\hline $\begin{array}{l}\text { Soil Reaction } \\
\text { (pH) }\end{array}$ & $<7.5$ & $7.5-8.5$ & $>8.5$ \\
\hline $\begin{array}{l}\text { Electrical } \\
\text { Conductivity } \\
\text { EC (ds m-1) }\end{array}$ & $<0.5$ & $0.5-1.0$ & $>1.0$ \\
\hline Organic Carbon & $<0.4$ & $0.4-0.75$ & $>0.75$ \\
\hline (OC \%) & & & \\
\hline
\end{tabular}

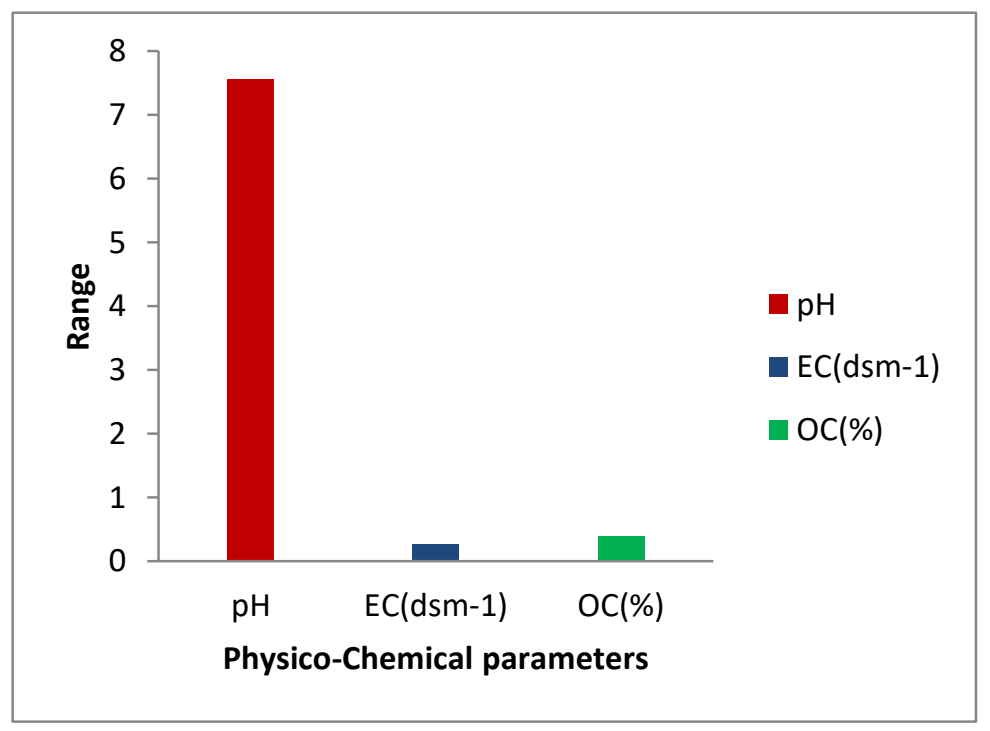

Figure No-2 Average mean value of pH, EC and OC status in Mayiladuthurai Taluk 


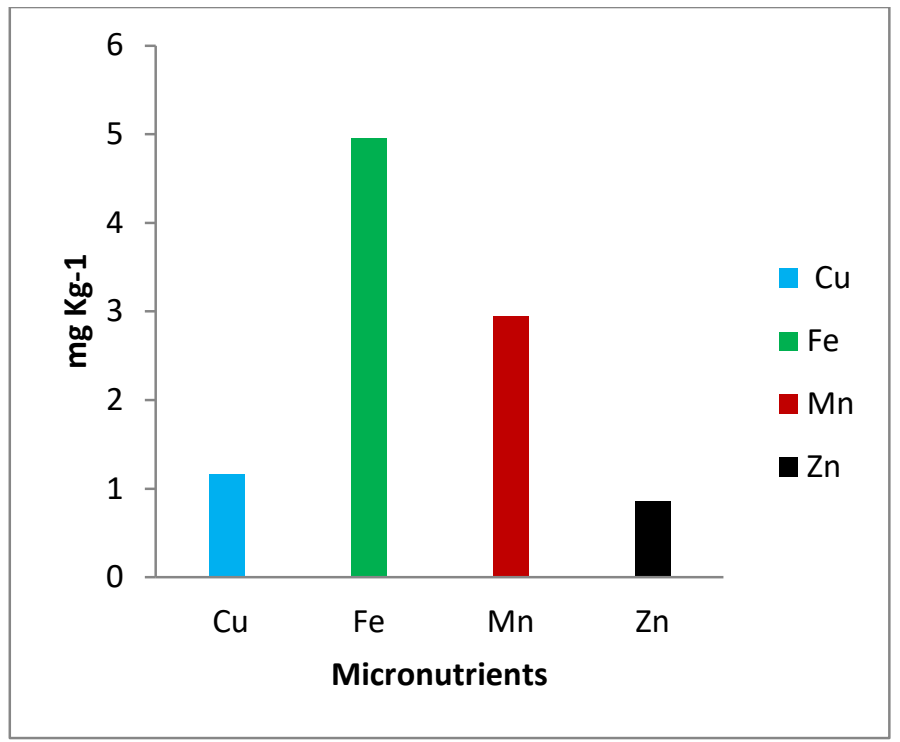

Figure No-3 Average mean value of Micronutrients status in Mayiladuthurai Taluk

Table-3. Deficiency percentage of Micronutrients status in Mayiladuthurai Taluk

\begin{tabular}{|c|c|c|c|c|}
\hline \multirow{2}{*}{ Details } & \multicolumn{4}{|c|}{ Deficiency of Micronutrients } \\
\cline { 2 - 5 } & Zn & Cu & Fe & Mn \\
\cline { 2 - 5 } & & & & \\
\hline Deficiency of Micronutrients (\%) & 90.24 & 90.24 & 12.19 & 26.82 \\
\hline Total number of Villages Deficient & 37 & 37 & 5 & 11 \\
\hline Total number of Villages Sufficient & 04 & 04 & 36 & 30 \\
\hline
\end{tabular}




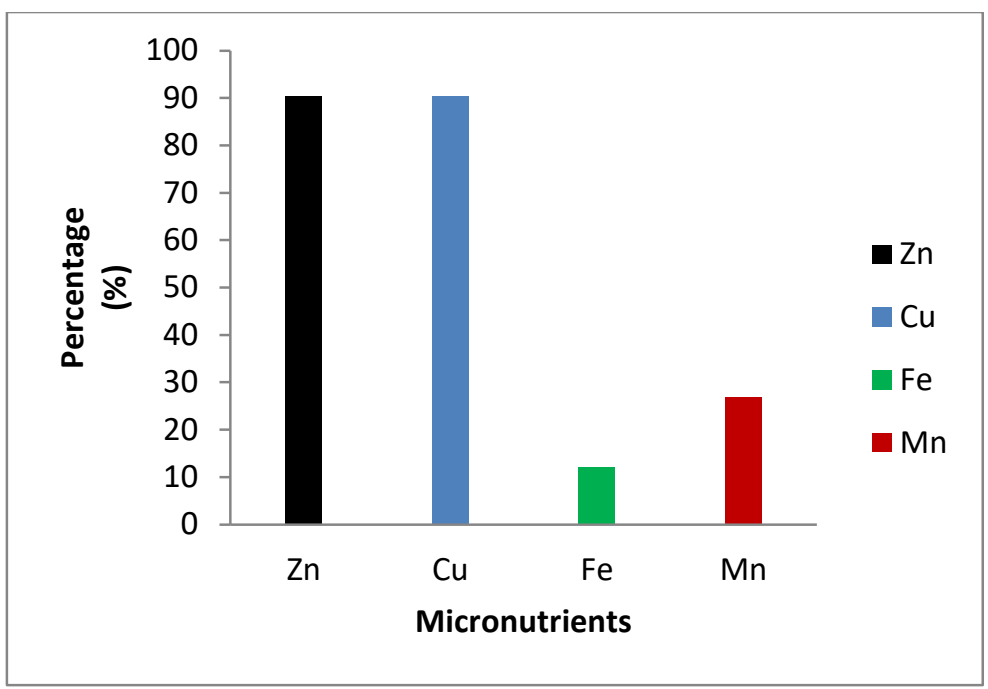

Figure No-4 Deficiency percentage of Micronutrients status in Mayiladuthurai Taluk

\section{Conclusion:}

The study revealed that the order of deficiency of micronutrients were found to be $\mathrm{Zn}>$ $\mathrm{cu}>\mathrm{Mn}>\mathrm{Fe}$. Gleaned from soil test and analysis of micronutrients was found that $\mathrm{Zn}$ deficiency was highest amid all the DTPA traceable micronutrients. Further, the availability of metal ions $(\mathrm{Fe}, \mathrm{Cu}$ ) increases with increase in organic matter content because organic matter content may supply chelating agents. The continued submergence of soils, calcareousness. $\mathrm{HCO} 3$ rich ground water, poor organic matter is the possible reasons for maximum $\mathrm{Zn}$ deficiency. Indiscriminate use of phosphate fertilizers and copper fungicides may also be attributed for $\mathrm{Zn}$ deficiency. Application of $\mathrm{ZnSO} 4$ as soil application and foliar sprays along with organic manures can enhance the availability of $\mathrm{Zn}$ in the study area. The symptoms of slacken, ungual tuberosity, necrosis is the possible reasons for maximum $\mathrm{Cu}$ deficiency. Indiscriminate use of copper oxychloride or cuprous oxide application in spray can enhance the availability of $\mathrm{Cu}$ in the study area.

\section{References}

1) Arokiayaraj, R. Vijayakumar and P. Martin Devaprasath (2011), Assessment of the status of micronutrients in Nagapattinam District, Tamilnadu, and Journal of Chemical Pharmaceutical research, 3(4): 10-16.

2) Broda E, Journal of Molecular Evolution, 1975, 7, 87.

3) Jagodin B A, Horticulture Abstracts. 1975, 11.257.

4) Lindsay $W L$ and Norwell $W$ A, Development of DTPA soil test for Zn, Fe, Mn and Cu. Soil Science, Society of American Journal. 1978, 42, 421-428. 
5) Martin Deva Prasath P. Assessment of Micronutrient status at Tiruchirappalli District, Tamil Nadu, proceedings of National Conference on 'Impending Approaches to Environmental Menace'. 2008, 117, 122.

6) Mhatre $\mathbf{G}$ N and Chaphekar S B, J.Environ.Bull. 1982, 3, 53.

7) Ruiter HJ (1969) Suspected copper deficiency in radiata pine. Plant Soil 31:197200.

8) Saucer K., Ace. Chemical Research, 1980, 13, 249.

9) Sharma, P.K., Anil Sood, Satia, R.K., Verma, V.K., Deepak Mehra, Tur, N.S., and Nayyar, V.K., Use of information technology for mapping of DTPA - extractable micronutrients in soils of Amristar District, Punjab. J.Indian Soc.Soil Sci., 2006, 54(4), 465-474.

10) Tandon HLS, Methods of Analysis of soils, plants, water and fertilizers, fertilizer Development and Consultation Organization, New Delhi, India, 1999, + VI, PP 144. 